University of New Hampshire

University of New Hampshire Scholars' Repository

Sociology Scholarship

Sociology

$12-2009$

\title{
Visualizing population dynamics of alaska's arctic communities
}

Lawrence C. Hamilton

University of New Hampshire, lawrence.hamilton@unh.edu

Angela M. Mitiguy

University of New Hampshire - Main Campus

Follow this and additional works at: https://scholars.unh.edu/soc_facpub

Part of the Sociology Commons

\section{Recommended Citation}

Hamilton, L.C., Mitiguy, A.M. Visualizing population dynamics of alaska's arctic communities. (2009) Arctic, 62 (4), pp. 393-398.

This Article is brought to you for free and open access by the Sociology at University of New Hampshire Scholars' Repository. It has been accepted for inclusion in Sociology Scholarship by an authorized administrator of University of New Hampshire Scholars' Repository. For more information, please contact Scholarly.Communication@unh.edu. 


\title{
Visualizing Population Dynamics of Alaska's Arctic Communities LAWRENCE C. HAMILTON ${ }^{1,2}$ and ANGELA M. MITIGUY'1,3
}

(Received 21 November 2008; accepted in revised form 3 February 2009)

\begin{abstract}
Arctic demography has previously been reviewed on a large scale, across the circumpolar nations. We look instead at some recent population dynamics on sub-regional to community scales, focusing on Arctic Alaska. Detailed graphics depicting yearly population changes from 1990 to 2006 in 43 selected Arctic Alaska towns and villages and all 27 of the state's "county-equivalent entities" (e.g., boroughs) have been published online in connection with two International Polar Year projects. Seemingly comparable places within the same borough have taken widely divergent paths. Birth rates generally exceed death rates, although both are high. Year-to-year and place-to-place variations are dominated not by natural increase, but by differences in net migration. Population changes influence demand for resources such as water, electricity, fuel, and capital improvements, and probably for subsistence resources as well. Migration rates provide sensitive indicators that integrate diverse internal and external pressures.
\end{abstract}

Key words: demography, population, migration, birth rate, mortality, Alaska, Arctic, village, demographic transition, Arctic Observing Network

RÉSUMÉ. La démographie de l'Arctique a déjà été étudiée à grande échelle, soit à la grandeur des nations circumpolaires. Ici, nous examinons plutôt certaines des récentes dynamiques de population de l'échelle sous-régionale à l'échelle communautaire, en nous concentrant sur l'Alaska de l'Arctique. Des graphiques détaillés illustrant les changements de population annuels de 1990 à 2006 dans 43 villes et villages choisis de l'Alaska de l'Arctique ainsi que dans tous les 27 « entités équivalant à des comtés » de l'État (des arrondissements par exemple) ont été publiés en ligne dans le cadre de deux projets de l'Année polaire internationale. Des endroits de toute apparence comparables au sein du même arrondissement ont pris des airs très divergents. Généralement, les taux de natalité dépassent les taux de mortalité, quoique les deux soient élevés. Les écarts d'une année à l'autre et d'un endroit à l'autre ne sont pas dominés par l'accroissement naturel mais plutôt par les différences caractérisant la migration nette. Les variations de la population exercent une influence sur la demande en ressources comme l'eau, l'électricité, le combustible et les améliorations apportées aux immobilisations, et probablement même sur les ressources de subsistance. Par ailleurs, les taux de migration fournissent des indicateurs sensibles qui tiennent compte de diverses pressions internes et externes.

Mots clés : démographie, population, migration, taux de natalité, mortalité, Alaska, Arctique, village, transition démographique, réseau d'observation de l'Arctique

Traduit pour la revue Arctic par Nicole Giguère.

\section{INTRODUCTION}

For the Arctic Human Development Report (AHDR, 2004), Bogoyavlenskiy and Siggner surveyed demographic conditions and compared trends across nine large sub-national regions: Alaska, Greenland, Iceland, the Faeroe Islands, and Arctic regions of Canada, Norway, Sweden, Finland, and Russia. The authors note contrasts among these regions, or between them and larger societies to the south. Distinctively Arctic characteristics include higher fertility and mortality, lower life expectancy, net outmigration, and younger age structures. Apart from these common elements, region-toregion variations reflect the stories of different places. With their high birth rates and youthful age structure, indigenous populations tend to have distinctive profiles even by Arctic standards (Bogoyavlenskiy and Siggner, 2004; Berner, 2008).

Stark contrasts could also be found within each of these large regions, however. The nine AHDR regions contain industrial and post-industrial cities such as Anchorage, Reykjavík or Murmansk, which dominate the statistical picture. But they also contain rural areas such as northwest Alaska, Iceland's Westfjords, or Russia's Chukotka. Most rural areas, in turn, contain a range of communities, from regional hubs with several thousand people and serviceoriented economies, to widely dispersed villages with hundreds or fewer people, often with mixed cash/subsistence economies. Scaling down to sub-regional or community

\footnotetext{
${ }^{1}$ Sociology Department, University of New Hampshire, Durham, New Hampshire 03824, USA

${ }^{2}$ Corresponding author: Larry.Hamilton@unh.edu

${ }^{3}$ E-mail: amx72@cisunix.unh.edu

(C) The Arctic Institute of North America
} 


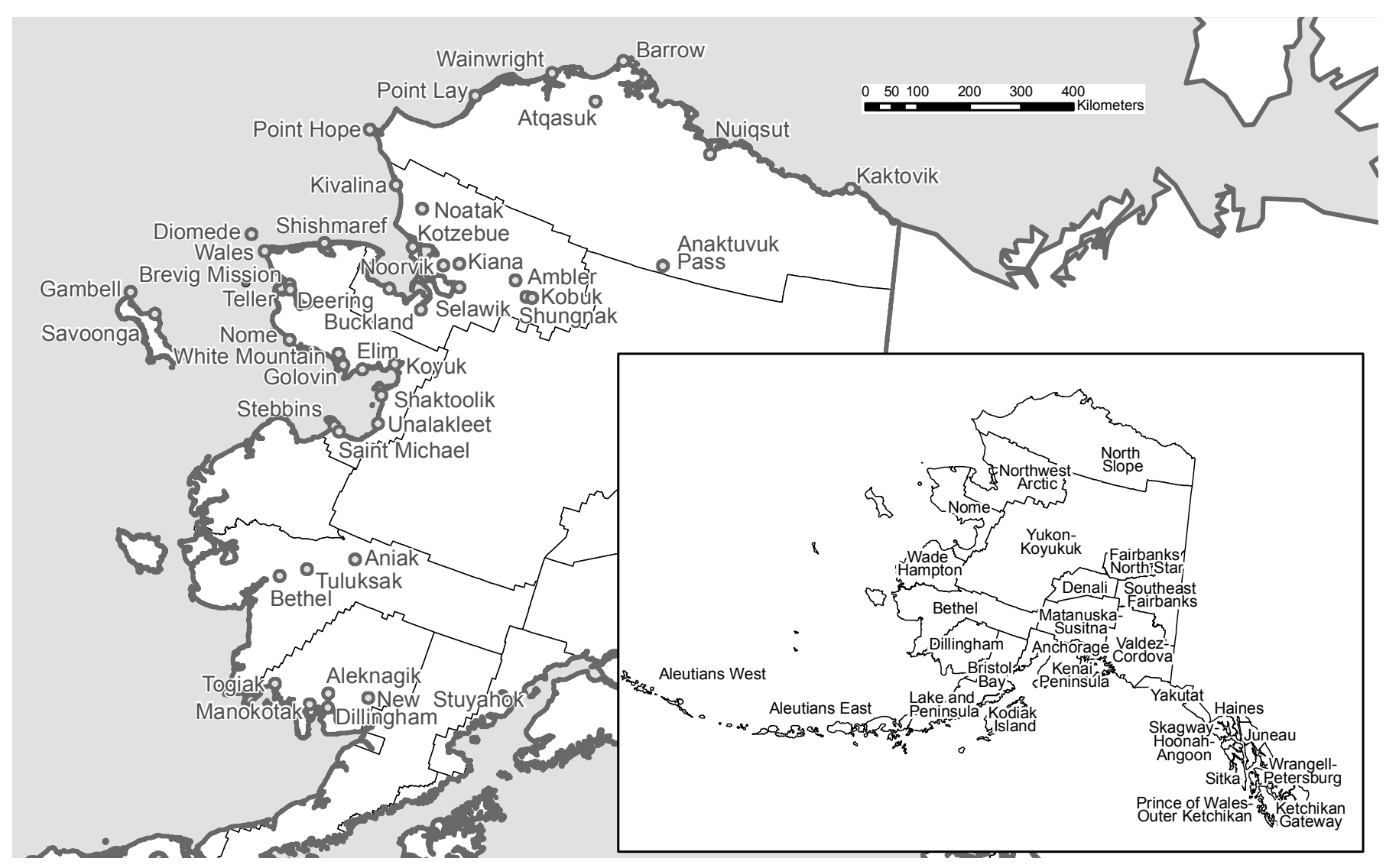

FIG. 1. Forty-three selected Arctic Alaska towns and villages (larger map), and 27 county-equivalent entities (boroughs, census areas, or municipalities) comprising all Alaska (inset). Map by Fay Rubin.

levels, while maintaining a broadly comparative perspective, presents an obvious next step for analysis.

Two recent projects have begun to assemble circumpolar human-dimensions databases at sub-regional scales: the Humans and Hydrology at High Latitudes (H3L) project (Arctic RIMS, 2008) and the Arctic Observing NetworkSocial Indicators project (AON-SI, 2008). In connection with these projects, we constructed a set of detailed graphics depicting population dynamics in 43 selected Arctic Alaska communities (Fig. 1). For a more complete background picture, we also graphed the 27 larger divisions (boroughs, municipalities, or census areas, viewed statistically as "county-equivalent entities") comprising the whole state. The initial library of 70 graphs, designed following principles suggested by Tufte $(1990,1997,2001)$, has been published online (Hamilton and Mitiguy, 2008). In this paper, we describe the information that the graphics convey, show examples of year-to-year and place-to-place variations, and look at broader patterns.

\section{GRAPHING COMMUNITY TRENDS}

Population change reflects the balance of births, deaths, and in- and outmigration. Figure 2 displays these flows for Kotzebue, the regional hub town of the Northwest Arctic
Borough. Bars along the lower part of the graph indicate the number of deaths (dark bars) and births (lighter bars) for each year from 1990 to 2006 (data from the Alaska Bureau of Vital Statistics). The number of deaths in a calendar year ranged from 8 to 21 , while 51 to 112 children were born to Kotzebue residents each year. (The seemingly exact counts of births, deaths, and population indicated by such graphs are of course subject to some errors.) A scale for deaths and births appears at lower right in Figure 2. On average, about 76 more births than deaths occurred each year. Without migration, the population would have continually increased.

Using a comparable vertical scale (marked at left in Fig. 2), the graph's main curve tracks total population, as estimated for most years by the Alaska Department of Labor and Workforce Development. The small jump in 2000 reflects the different methods and timing of the U.S. Census count. For non-Census years (all but 1990 and 2000), the state provides estimates based on administrative data, notably Permanent Fund Dividend applications - a unique data resource permitting what the U.S. Census Bureau has judged to be the most accurate yearly estimates of any U.S. state (Alaska Department of Labor and Workforce Development, 2008).

Vertical line segments that extend above the main curve in Figure 2 indicate net outmigration, inferred from a 


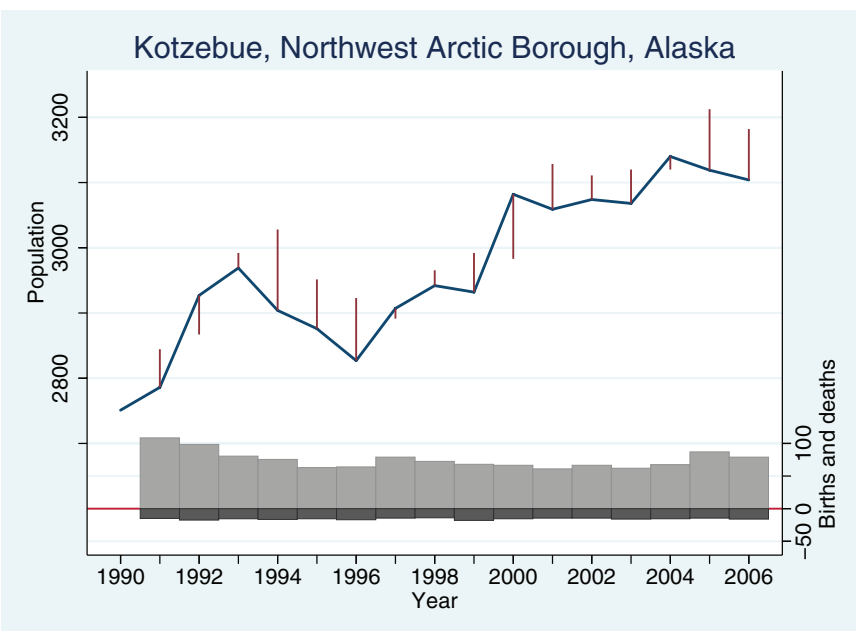

FIG. 2. Population dynamics (total, births, deaths, and net migration) of Kotzebue, Alaska, 1990-2006. The vertical lines show estimated net migration effects.

population estimate that is lower than would be expected as a result of natural increase alone. For example, Kotzebue's estimated population for July 1, 2005 was 3119. Natural increase, or births minus deaths, leads to a 2006 projection of 3182, indicated by the top of a vertical line segment. (Because population estimates are for midyear, whereas vital statistics describe calendar years, we employed a linear approximation for births and deaths between midyear points.) The Department of Labor and Workforce Development estimated the actual 2006 population as 3104, so the line segment extends down from 3182 to the main population curve at 3104 , denoting net outmigration of 78 people. Vertical line segments that extend below the main curve indicate net in-migration, or population growth exceeding that expected from natural increase.

Figure 2 suggests that between 1990 and 2006, Kotzebue experienced net in-migration in only four years (1992, 1997, 2000, and 2004); in all other years, more people left than arrived. The average was a loss of 37 people, partially offsetting natural increase, so that total population grew slowly or sometimes declined.

A variety of different patterns occurred in smaller villages within the same borough. Figure 3 depicts changes in Selawik, Ambler, Deering, and Buckland. Selawik, unlike Kotzebue, experienced relatively little net migration. Its population climbed by more than $40 \%$ during this period, compared with just $13 \%$ in Kotzebue, where most of the jobs are. Selawik's growth resulted from natural increase, accelerated by a statistically significant rise in birth rate.

Elsewhere in the Northwest Arctic Borough, birth rates remained steady or declined, while net migration played a greater role. Large year-to-year fluctuations occurred in both Ambler and Deering, where populations declined despite the excess of births over deaths. In Buckland, net outmigration roughly stabilized the population in recent years. All of these places have predominantly Alaska Native (mainly Iñuat) populations-over $70 \%$ in Kotzebue, and $87 \%$ or more in the villages. The divergent population trends of five culturally and economically linked Northwest Arctic communities in Figures 2 and 3 invite detailed study. What is happening in Selawik that drives the rising birth rate, but minimizes net migration? Conversely, why have opposite patterns prevailed in Ambler? Similar diversity can be found across other Arctic Alaska communities (Hamilton and Mitiguy, 2008). Case studies that include ethnographic work, perhaps down to the level of families, could prove useful for understanding how such differences reflect economic and social conditions.

\section{PATTERNS OF CHANGE}

In his historical ethnography, Burch (2006:7) gives population estimates for northwestern Alaska in the early contact period. Burch's study area is somewhat larger than the modern Northwest Arctic Borough, but overlaps enough to permit an interesting historical comparison: there were 7315 people in 1800 , compared with a borough population of 7334 in 2006. The modern population, though comparable in size, has become much more concentrated in a small number of places. For example, Burch reports that in 1800 , the Kotzebue district contained 390 people, whereas in 2006 the town of Kotzebue had more than 3100 .

As Figures 2 and 3 suggest, each place has its own story. In the case of villages, different growth paths could reflect subtle differences in social and family networks, education or economic contingencies. But if we step back and view many such graphs together, some broad patterns become visible across the 43 communities in our data.

- Arctic Alaska towns and villages tend to have relatively high birth rates and, despite above-average mortality, high potential for natural increase.

- Natural increase in these towns and villages ranged from about $-1 \%$ to $+5 \%$ per year.

- Net migration was much more variable than natural increase, ranging from $-21 \%$ to $+30 \%$.

- Migration flows can respond quickly to changing conditions, including opportunities elsewhere.

- On average, most places experienced net outmigration over this period.

- Under some conditions, net outmigration offsets natural increase, resulting in population stability or decline.

- Otherwise, population shows a tendency to increase. Many places grew by $30 \%$ or more, without net in-migration, from 1990 to 2006.

Crude birth rates among the 43 towns and villages in Figure 1, averaged over 1990-2006, ranged from 13 to 40 births per thousand population, with a median of 26. Crude death rates ranged from 4 to 11 per thousand, with a median of 6. For comparison, the city of Anchorage experienced a birth rate of 17 over this period and a death rate of 4 , while general U.S. rates were around 14 and 8. 

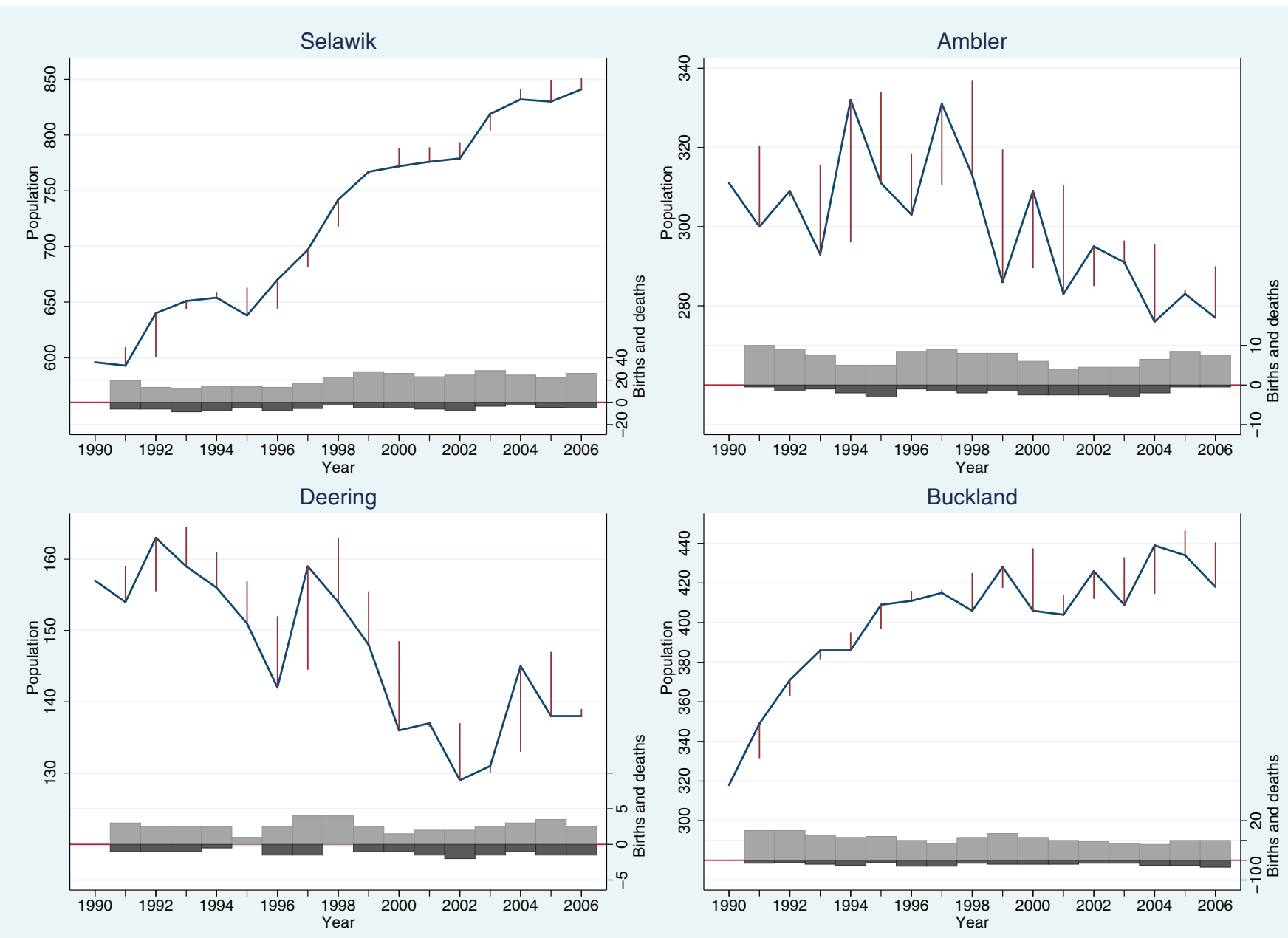

FIG. 3. Population dynamics of four smaller Northwest Arctic Borough villages, 1990-2006. Vertical line segments show estimated net migration effects. Note the different scales used in each graph.

Their birth, death, and net migration rates help to characterize Arctic communities with respect to the demographic transition. This model describes how societies change from a pre-modern state of high fertility and high mortality to a post-industrial state of low fertility and low mortality (Thompson, 1929; Notestein, 1945). A common formulation divides the transition into four stages (Hall, 1972; Montgomery, 2007):

Stage 1, pre-modern: fluctuating high birth and death rates (especially infants and children) keep population growth erratic and slow.

Stage 2, urbanizing/industrializing: mortality declines while birth rates remain level or increase, leading to rapid population growth.

Stage 3, mature industrial: falling birth rates slow down the rate of population growth, but the absolute population is now much larger.

Stage 4, post-industrial: birth rates vary with economic conditions but are comparable to death rates, making the population roughly stable.
With fertility rates much higher than mortality rates, the communities of Arctic Alaska resemble Stage 2 in the demographic transition. Other parts of the state, with somewhat lower fertility, appear closer to Stage 3.

Relatively large migration flows tend to dominate Arctic population change, however. In this respect, Arctic places depart substantially from the demographic transition model. Some places grow rapidly, in typical Stage 2 fashion. Others remain stable or decline because outmigration more than compensates for natural increase. Age and gender patterns in migration rates (young adults and females are more likely to leave) further reshape the age-sex structure of Arctic community populations in ways not predicted by the demographic transition (Hamilton and Seyfrit, 1994a, b; Hamilton, in press). Variations in migration rates likely reflect a mix of economic forces and more subtle social influences. For example, schools and families that successfully prepare young people for jobs and education elsewhere could increase outmigration, and yet paradoxically reflect community strength. Conversely, outmigration could be low either because of the positive attractions of home or, more negatively, because the exit doors appear closed. Similar 

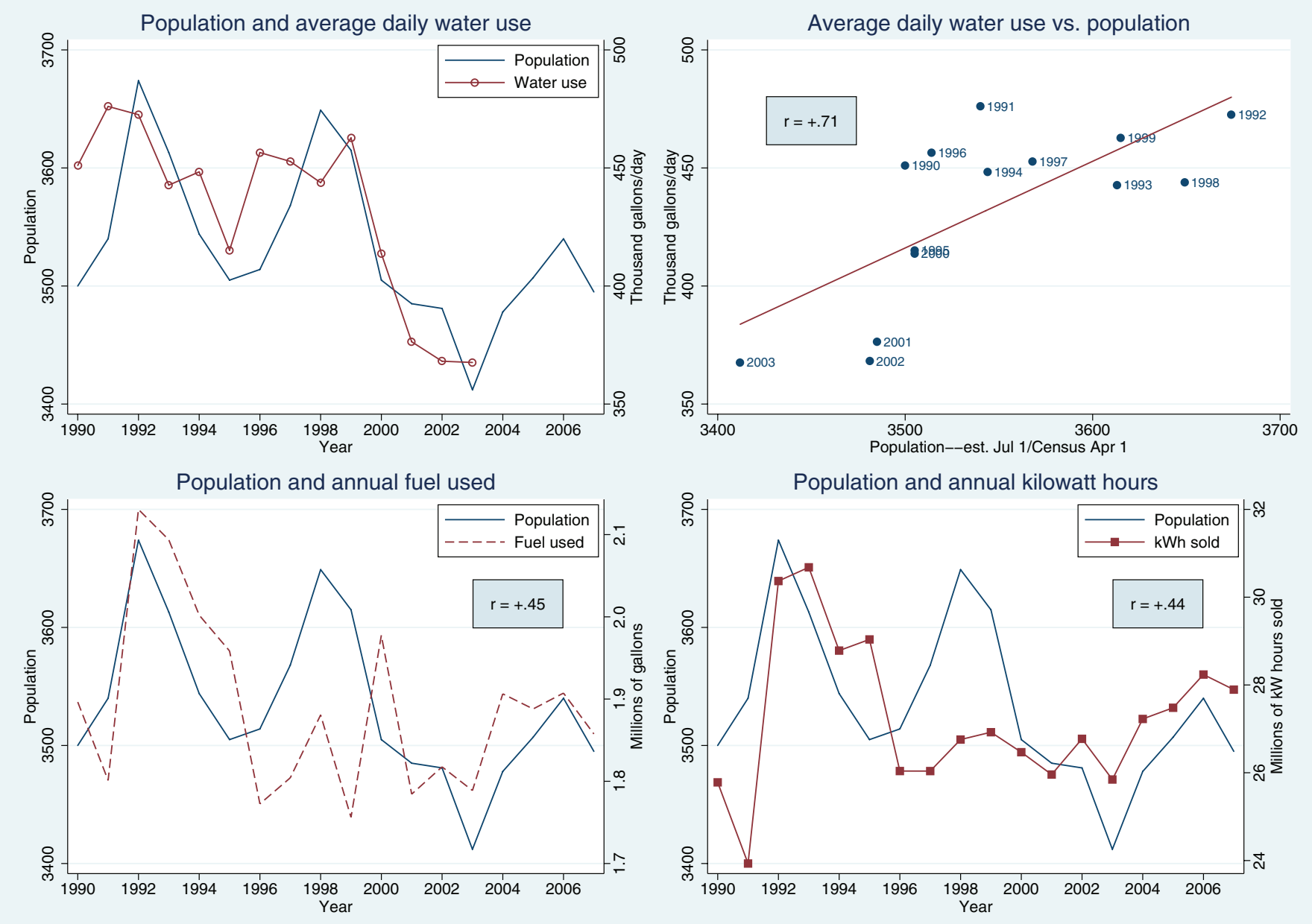

FIG. 4. Population and water, fuel, and electricity use in Nome, Alaska, 1990-2007. (a) Average water consumption by the community (thousands of gallons per day) and population; (b) Average daily water consumption vs. population; (c) Fuel used each year to generate electricity in the community (millions of gallons) and population; (d) Total electricity sold in the community (millions of kilowatts per year) and population.

dynamics operate not just at regional or community levels, but also for individuals and families.

A companion to the demographic transition model, termed the health or epidemiological transition, describes long-term shifts in mortality from "pestilence and famines" to "degenerative and human-made diseases" (Young and Bjerregaard, 2008:15). The latter include problems related to diet and behavior. Suicide contributes to the high mortality in many Arctic places (Hild and Stordahl, 2004). Some evidence suggests that among Inuit communities, suicide rates themselves have followed a transition pattern, peaking at intermediate levels of modernization (Hicks, 2007). High mortality rates from a variety of human-made causes remain matters of great concern for Arctic communities (Hild and Stordahl, 2004; Young, 2008; Young and Bjerregaard, 2008), including many of those in our data. A worthwhile project for future research could be to assemble health measures for the same places we cover demographically and explore possible correlations between community-level health indicators and net migration.
Population changes alter many social and economic aspects of community life. They have consequences for the environment as well, including demand for resources. Figure 4 graphs population changes in the town of Nome together with water, fuel, and electricity use for the years from 1990 to 2007. All three resources exhibit positive correlations with the Nome population, although clearly other factors are involved. Similar correlations exist for other Seward Peninsula communities, such as Brevig Mission and Shishmaref, in data assembled by Greta Myerchin and Dan White for the H3L project (Arctic RIMS, 2008). Population change seems likely to change pressures on living resources as well. Through environmental impacts, population could indirectly affect vulnerability to environmental shifts, including those related to climate.

\section{DISCUSSION}

Net migration requires context to interpret, but with appropriate background, it provides a key indicator of 
community impacts from external pressures. The outside forces affecting these small places are likely to grow stronger in the years ahead as climate change, economic and energy troubles, and ecological shifts become more acute. Migration has proven to be capable of very quick response to changing conditions.

Today, some remote communities find themselves on the front lines of global change. Built along coastlines where sea ice no longer protects shores from erosion by fall storms, Alaska villages such as Shismaref or Kivalina provide images and legal test cases of damage from Arctic warming (Faris, 2008). Other communities, such as Barrow, were transformed by the development of North Slope oil (Chance, 1990) and stand to change further as energy developments wax and wane. Commercial fishing towns such as Dillingham or Togiak, which are south of the Arctic Circle but still linked to the Arctic system, struggle to cope with the economic impacts of Bering Sea changes, globalized markets, and overfishing. Fluctuating fuel costs will have great effects on them all, as will the national and global economies.

Integrating diverse forces, the populations of some places have grown rapidly, while others have declined or shown erratic fluctuations. Net migration - whether inflows of newcomers seeking jobs or outflows of natives or former newcomers seeking opportunities elsewhere-dominates both year-to-year and place-to-place variation of population change in Arctic Alaska. At the same time, apparently systematic differences among places exposed to similar conditions raise questions for more detailed research.

\section{ACKNOWLEDGEMENTS}

The research described here represents a contribution to the International Polar Year. Work was conducted under the AON-SI and H3L projects, supported by grants from the Arctic Social Sciences and Arctic System Science programs at the U.S. National Science Foundation (OPP-0638413 and OPP-0531354).

\section{REFERENCES}

AHDR. 2004. Arctic Human Development Report. Akureyri: Stefansson Arctic Institute.

Alaska Department of Labor and Workforce Development. 2008. Methods for the Alaska population estimates. http://www. labor.state.ak.us/research/pop/estimates/AKPopEstMethods. pdf.

AON-SI. 2008. Arctic Observation Network Social Indicator Project. http://www.iser.uaa.alaska.edu/projects/search-hd.

Arctic RIMS. 2008. A regional, integrated hydrological monitoring system for the Pan-Arctic land mass. http://rims.unh.edu/.
Berner, J. 2008. Alaska. In: Young, T.K., and Bjerregaard, P., eds. Health transitions in Arctic populations. Toronto: University of Toronto Press. 53-70.

Bogoyavlenskiy, D., and Siggner, A. 2004. Arctic demography. In: The Arctic human development report. Akureyri: Stefansson Arctic Institute. 27-41.

Burch, E.S. 2006. Social life in Northwest Alaska: The structure of Iñupiaq Eskimo nations. Fairbanks: University of Alaska Press.

Chance, N.A. 1990. The Iñupiat and Arctic Alaska: An ethnography of development. Fort Worth, Texas: Holt, Rinehart and Winston.

Faris, S. 2008. Conspiracy theory. The Atlantic 301(5):32-34.

Hall, R.L. 1972. The demographic transition: Stage four. Current Anthropology 13(2):212-215.

Hamilton, L.C. In press. Footprints: Demographic effects of outmigration. In: Huskey, L., and Southcott, C., eds. Migration in the Circumpolar North: Issues and contexts. Edmonton, Alberta: Canadian Circumpolar Institute.

Hamilton, L.C., and Mitiguy, A. 2008. Population dynamics in Arctic Alaska: Graphical views of community change. http:// www.carseyinstitute.unh.edu/alaska-indicators.htm.

Hamilton, L.C., and Seyfrit, C.L. 1994a. Female flight? Gender balance and outmigration by Native Alaskan villagers. Arctic Medical Research 53(Supplement 2):189-193.

1994b. Coming out of the country: Community size and gender balance among Alaskan Natives. Arctic Anthropology 31(1):16-25.

Hicks, J. 2007. The social determinants of elevated rates of suicide among Inuit youth. Indigenous Affairs (April):30-37.

Hild, C.M., and Stordahl, V. 2004. Human health and well-being. In: Arctic Human Development Report. Akureyri: Stefansson Arctic Institute. 155-168.

Montgomery, K. 2007. The demographic transition. http://www. uwmc.uwc.edu/geography/Demotrans/demtran.htm.

Notestein, F. 1945. Population-The long view. In: Schultz, T., ed. Food for the world. Chicago: University of Chicago Press. 36-58.

Thompson, W.S. 1929. Population. American Journal of Sociology 34:959-975.

Tufte, E.R. 1990. Envisioning information. Cheshire, Connecticut: Graphics Press.

- 1997. Visual explanations: Images and quantities, evidence and narrative. Cheshire, Connecticut: Graphics Press.

- 2001. The visual display of quantitative information, 2nd ed. Cheshire, Connecticut: Graphics Press.

Young, T.K. 2008. Circumpolar health indicators: Sources, data, and maps. Circumpolar Health Supplements 3. Oulu, Finland: International Association of Circumpolar Health Publishers. $128 \mathrm{p}$.

Young, T.K., and Bjerregaard, P., eds. 2008. Health transitions in Arctic populations. Toronto: University of Toronto Press. 